\title{
Affirmative Action in Post-Secondary Education: Contrasting Approaches in Brazil and Canada
}

\author{
Michelli Aparecida Daros ${ }^{1}$, Diandra Singh ${ }^{2}$ \\ ${ }^{1}$ Ph.D Candidate at Pontifical Catholic University of São Paulo, Visiting Doctoral Researcher at Université du Québec \\ en Outaouais, São Paulo, Gatineau, Brazil, Canada, michellidaros@gmail.com \\ ${ }^{2}$ Ph.D Candidate at The University of Ottawa, Ottawa, Canada,dsing022@uottawa.ca
}

\begin{abstract}
This paper compares and contrasts approaches to affirmative action that are intended to increase access to post-secondary institutions to students racialized as Black and Indigenous in Brazil and Canada, respectively. Both of these demographics are underrepresented in post-secondary institutions in these countries, as a result of the legacy of colonization and systemic racism within these nations. To explore various approaches to affirmative action a comparison of several documents are made including: the Brazilian Federal Law 11.645/ 2008, which obliges the addition of the History and Culture of AfroBrazilians and Indigenous people to the national curriculum; the Brazilian Federal Law 12.711/2012, which supports access to federal universities and other federal educational institutions through quotas (best known as the "Quotas' Law"); and the Truth and Reconciliation Final Summary Report (2015), which provides 94 calls to action for the Canadian government to redress the issues created by the residential school system. Through document analysis, a list of affirmative actions is compiled, followed by an analysis of their implementation. Moreover, data related to racialized students who have benefited from these approaches, highlight the importance of affirmative actions to build more inclusive democratic systems.
\end{abstract}

KEYWORDS: affirmative action, post-secondary education, Brazil, Canada, racialized minorities

\section{Introduction}

Affirmative action is a controversial topic around the world (Sowell 2004). It entails providing preferential treatment to a specific group (usually a minority group) to bolster their opportunities in various aspects of life (e.g. education and employment). The rationale for giving specific groups preferential treatment is that societies are embedded with inequalities which hinder the opportunities of some groups (Kellough 2006). Thus, there have been a number of approaches to implement affirmative action including: 1) the passing of laws that prohibit discrimination and the implementation of procedures to investigate cases of discrimination; 2) gathering and analyzing statistics on various groups (e.g. admission rates); 3) enabling certain groups to have upward mobility (e.g. within the workforce); 4) increasing recruitment efforts for certain demographics and setting goals/quotas (Kellough 2006). The controversy surrounding affirmative action stems from the belief that those who do not receive affirmative action are being discriminated against and it has even been argued that these programs have a global legacy of being unsuccessful and even detrimental to society (Sowell 2004). Those who argue against affirmative action (e.g. Sowell 2004), take a narrow view of it relegating it to preferential treatment for one group and claim that affirmative action has caused tensions between various racialized groups. We depart from this view of affirmative action as we believe it encompasses the 4 points mentioned above and we also believe that affirmative action is not the root cause of animosity between racialized groups specifically in the contexts of Canada and Brazil, we believe that the root cause is colonization.

We recognize the complexity of affirmative action and the various approaches to its implementation within different regions. Therefore, we turn our attention to the case of affirmative action initiatives in Canada (for Indigenous groups) and Brazil (for Indigenous and Afro-Brazilians) that pertain to post-secondary education. Through document analysis we seek to answer the questions: What are documented approaches/calls to affirmative action? How have they been put into practice? The documents we compare include: the Brazilian Federal Law 11.645/ 2008, which obliges the addition of the History and Culture of Afro-Brazilians and Indigenous people to the national curriculum; the Brazilian Federal Law 12.711/2012, which supports access to federal universities and other federal educational institutions through quotas (best known as the "Quotas' Law"); and the Truth and Reconciliation Summary Report (Truth and Reconciliation Commission 
of Canada 2015), which provides 94 calls to action for the Canadian government to redress the issues created by the residential school system. In what follows we briefly describe the context of education in these nations, we describe the documents that are analyzed, we outline the approaches to affirmative action that we found, we discuss our results in their respective contexts, and conclude with our thoughts on these approaches.

\section{Educational Contexts}

\section{Canada and Educational Systems for Indigenous Peoples}

In Canada, education is provincially mandated and funded for everyone except when it comes to Indigenous Peoples - First Nations, Inuit, Metis (FNIM) - who are funded (actually underfunded) by the federal government (Carelton 2016). Underfunding is the lesser evil that FNIM have experienced from the federal government, when it comes to educational policies and specifically the residential "school" system. Residential "schools" operated in Canada between the 1830s and the mid-1990s (Legacy of Hope Foundation 2001). They were also funded, supported, and implemented by several church groups (Roman Catholic, Methodist, Anglican, Presbyterian and United) (Legacy of Hope Foundation 2001). Although, each residential "school" operated differently and some students did enjoy their experience, negative experiences prevailed across most "schools" (Truth and Reconciliation Commission of Canada (TRC) 2015). Once an Indigenous child was of an eligible age to attend school, she or he would be apprehended and sentenced to the residential "school" system.

There were various negative consequences at these "schools" including: separation from family and their community; the loss of language and traditions; low expectations; child labor; bullying; verbal abuse; sickness; hunger; physical abuse; sexual abuse; and death (TRC 2015). These institutions had a mortality rate of 50\% (Walker 2009) and were a form of cultural genocide (TRC 2015). Some of the legacies of residential "schools" that persist today among FNIM are a loss of language, loss of culture, poor health, a lack of parenting skills, many FNIM children in Childwelfare, various maladaptive behaviours (e.g. abuse, drugs, alcohol, criminal activity), a distrust of schools, and low levels of educational attainment. Therefore, we examine the calls for affirmative action that have been set in place to combat the legacies of residential "schools."

\section{Brazil and Educational Attainment of various Racialized Groups}

Similar to Canada, Brazil is experiencing the legacy of colonization through a number of disparities between racialized groups. Brazil - a country colonized by Portuguese people, and built with Indigenous, African, European, and Asian immigrants - consists of a huge diversity of cultures and traditions. Brazil is the largest country in South America and its current population is roughly 205 million people (IBGE 2017). The Brazilian Institute of Geography and Statistics (IBGE) develops seasonal surveys to track the main trends of the population. Regarding racialization, an analysis of self-declarations, the Brazilian population is basically comprised of those racialized as white (44.2\%), mixed-race (pardos in Portuguese) (46.7\%), and black (8.2\%). The category of pardos itself is useful to demark the social, economic and educational inequalities between those racialized as non-white and white, although some authors like Moraes Silva \& Souza Leão (2012) argue that the term is not sufficient to represent all cultural and economic symbols and barriers that those racialized as pardos face.

As a result of historical-political-economic oppression - which has affected non-white Brazilians since colonization and slavery times - there are a number of disparities between those racialized as "white" and those who are not. According to PNAD (2017), the monthly average wage of white Brazilians was roughly 2800, reais (723 USD), whereas black people and pardos people received 1.570 reais (405 USD), and 1.606 reais (415 USD), respectively. Inequalities extend to education: Illiteracy rates are $4.0 \%$ for those racialized as white and $9.3 \%$ for those racialized as black and pardos (PNAD 2017). Considering that access to post-secondary education requires prior 
elementary and high school education, trends in Brazilian post-secondary education attainment tend to perpetuate the already existing educational-social-economic inequality. Just $9.3 \%$ of those racialized as non-white and over 25-year-olds hold a post-secondary degree against $22.9 \%$ of Brazilians racialized as white (PNAD 2017). However, studies conducted by the Brazilian government claim that gradually, the educational attainment scenario has been moving towards increasing access to upper education for those racialized as non-white. An IBGE (2015) report showed that in 2004, just $16.7 \%$ of students racialized as non-white (black and pardos) at the age 18-24-year-olds were attending post-secondary education, and in 2014, this rate increased to $45.5 \%$.

Affirmative action efforts have been a part of the process of spreading post-secondary education to those who have been historically excluded. Both Brazil and Canada have taken affirmative action steps in these areas, in hopes of redressing disparities. For this reason, we examine key documents for the types of affirmative action that they have posited and to explore how these actions have been put into practice.

\section{Key Documents}

\section{Truth and Reconciliation Summary Report}

The Truth and Reconciliation Report is a multivolume collection that recounts the residential "school" experience. It is based on an extensive project put together by the Truth and Reconciliation Commission of Canada (TRC 2015). The TRC was created in 2008 as a result of a settlement agreement for residential "school" survivors (Moran 2017). It was intended to reveal the truth about the residential "school" system and to lay the groundwork for reconciliation across the country. The commission organized events across Canada to gather the testimonies of FNIM residential "school" survivors,' it also collected relevant documentation that was related to the operation of the residential "school" system, and created the National Research Center for Truth and Reconciliation, and created the aforementioned report (Moran 2017). The final summary report is a condensed version of the multivolume work, which concludes with several calls to action. We analyze these calls to action for affirmative action approaches that are specifically related to education.

\section{Brazilian Federal Law 11.645/2008 and Federal Law 12.711/2012}

In 2003, the first Federal Law that introduced Afro-Brazilian culture to the curricula of public schools in Brazil was proclaimed. However, the law was considered narrow because it did not include topics regarding Indigenous culture and history. (Silva 2014). Thus, in 2008, this law was succeeded by the Federal Law 11.645/2008, which includes the teaching of Indigenous culture and history along with the teaching of Afro-Brazilian culture and history in the national curricula guidelines (specifically for elementary and high school curricula, but also having major implications for post-secondary teacher education programs), answering to social and political Afro-Brazilian and Indigenous movements at the time.

It is fundamental to mention that following this law, the National Equality Racial Statute (Estatuto da Igualdade Racial), a substantial federal law was passed, defining all pardos(mixed race) people as racialized as black, and victims of racism due to the fact that they are not considered racialized as white. In addition, the National Equality Racial Statute defined affirmative action as "the special programs and measures adopted by the State and by the private initiative for the correction of racial inequalities and for the promotion of equal opportunities" (Brasil 2010, 13). This law ushered in great political fervour that promoted additional affirmative action in Brazil. As a result, the Federal Law 12.711/2012, better known as Lei de Cotas (Quotas' Law) was published in 2012, as a necessary means to encourage social mobility through increased access to postsecondary institutions (Valente \& Berry 2017).

Thus, the Quotas' Law, the Federal Law 11.645/2008, and the TRC Report are monumental documents in their respective nations. They similarly put forth measures to make society more 
equitable and they both utilize strategies that we qualify as affirmative action. Given the significance of these documents, we examine their affirmative action strategies to outline thematic approaches to affirmative action that are being utilized in these countries, to highlight any differences, and to explore how these countries have attempted to implement these approaches.

\section{Results: Approaches to Affirmative Action}

Although the TRC summary of the final report (2015) did not directly use the word affirmative action, we found that it contained several calls to action that encompassed our 4 point definition of affirmative action (passing of laws that prohibit discrimination and enable investigation of it, gathering and analyzing statistics on various groups, enabling certain groups to have upward mobility and increasing recruitment efforts for certain demographics and setting goals/quotas). After analyzing the 94 calls to action and determining which calls were relevant to post-secondary education (those that mentioned post-secondary education, curricula, etc.), we found that these calls could be categorized based on 4 main affirmative action approaches: 1) to create a strategy for equitable access to education; 2) to collect data on FNIM and to release findings to the public; 3) to provide funding to support various FNIM initiatives related to education; and 4) to include culturally appropriate curricula.

Table 1. Approaches to affirmative Action based on the TRC's Calls to Action

\begin{tabular}{|l|l|l|}
\hline Affirmative Action Approach & \multicolumn{1}{|c|}{$\begin{array}{c}\text { Calls } \\
\text { to Action }\end{array}$} & Excerpts from the TRC's (2015) calls to action \\
\hline $\begin{array}{l}\text { To create a strategy for } \\
\text { equitable access to education }\end{array}$ & 7,10 & $\begin{array}{l}\text { "We call upon the federal government to develop } \\
\text { with Aboriginal groups a joint strategy to eliminate } \\
\text { educational and employment gaps between } \\
\text { Aboriginal and non-Aboriginal Canadians" (p. 195). }\end{array}$ \\
\hline $\begin{array}{l}\text { To collect data on FNIM and to } \\
\text { release findings to the public }\end{array}$ & $9,10,55$ & $\begin{array}{l}\text { "We call upon the federal government to prepare } \\
\text { and publish annual reports... [on] educational and } \\
\text { income attainments of Aboriginal peoples in Canada } \\
\text { compared with non-Aboriginal people" (p. 196). }\end{array}$ \\
\hline $\begin{array}{l}\text { To provide funding to support } \\
\text { various FNIM initiatives related } \\
\text { to education }\end{array}$ & $8,10,11$, & $\begin{array}{l}\text { "We call upon the federal government to provide } \\
\text { adequate funding to end the backlog of First Nations } \\
\text { students seeking a post-secondary education" (p. } \\
\text { 199). }\end{array}$ \\
\hline $\begin{array}{l}\text { To include } \\
\text { appropriate } \\
\text { curricula/programming }\end{array}$ & $62,64,87$ & $\begin{array}{l}\text { "We call upon post-secondary institutions to create } \\
\text { university and college degree and diploma programs } \\
\text { in Aboriginal languages" (p. 205). }\end{array}$ \\
\hline
\end{tabular}

Similar to the approaches in the TRC summary report the two Brazilian federal laws did not mention the word affirmative action. However, the laws met the criteria of our definition of affirmative action as they relate to recruitment efforts. Although the Brazilian Federal Law $11.645 / 2008$ is about providing culturally relevant curricula to Indigenous and Afro-Brazilians, we view this as a way of supporting learners' recruitment and retention through the use of engaging/relevant curricular content. The Federal Law 11.645/2008 represents the starting of a nationwide affirmative action process in Brazil and was a key stepping stone for the Quotas' Law, which is a clear example of an affirmative action as it requires that $50 \%$ of all places existent in 
post-secondary federal institutions are reserved for black, pardos (mixed-race) and students economically vulnerable. In an effort to make the mechanism of this law clear, Valente and Berry elaborate $(2017,21)$

\begin{abstract}
Within this quota, half of all slots are allocated to students whose family income is less than or equal to 1.5 minimum wages per person in the household. Within this quota, slots are reserved for black, [pardos], and indigenous students in proportion to the percentage of these groups in the state where the university is located. In the state of São Paulo, for example, approximately 30 percent of the population is black, brown, or indigenous, whereas in Bahia this number is close to 76 percent. According to this new law, if the specified racial groups do not fill the quota slots, then the available slots should go to students who studied only in public high school. The implementation of quotas has occurred progressively: federal universities were to reserve 12.5 percent of total slots in 2013, 25 percent in 2014, 37.5 percent in 2015, and 50 percent in 2016.
\end{abstract}

Table 2. Approaches to Affirmative Action based on the Federal Law 11.645/2008 and the Quotas' Law $^{1}$

\begin{tabular}{|l|l|l|}
\hline $\begin{array}{l}\text { Affirmative Action } \\
\text { Approach }\end{array}$ & Law & Excerpt \\
\hline $\begin{array}{l}\text { To create a strategy for } \\
\text { equitable access to } \\
\text { education }\end{array}$ & $\begin{array}{l}\text { Quotas' } \\
\text { Law- } \\
\text { Federal Law } \\
12.711 / 2012\end{array}$ & $\begin{array}{l}\text { "In filling of the spots referred to in the caput of this } \\
\text { article, 50\% (fifty percent) shall be reserved for students } \\
\text { from families with income equal to or less than 1.5 } \\
\text { minimum wage (one minimum wage and one half) per } \\
\text { capita... Article 3. In each federal institution of higher } \\
\text { education, the spots referred in Art. 1 of this Law will be } \\
\text { filled, per course... by self-declared blacks, pardos and } \\
\text { indigenous people ..." (Brasil 2012) }\end{array}$ \\
\hline $\begin{array}{l}\text { To include culturally } \\
\text { appropriate } \\
\text { curricula/programming }\end{array}$ & $\begin{array}{l}\text { Federal Law } \\
11.645 / 2008\end{array}$ & $\begin{array}{l}\text { "§1. The programmatic content ...will include several } \\
\text { aspects of the history and culture that characterize the } \\
\text { formation of the Brazilian population, from these two } \\
\text { ethnic groups, such as the study of ....the struggle of the } \\
\text { blacks and indigenous peoples in Brazil, black and } \\
\text { indigenous Brazilian culture and black and indigenous } \\
\text { populations in the formation of national society rescuing } \\
\text { their contributions in the social, economic and political } \\
\text { areas, pertinent to the history of Brazil." (Brasil 2008) }\end{array}$ \\
\hline
\end{tabular}

Our analysis of the TRC final summary report (2015), the Federal Law 11.645/2008, and the Quotas' Law yielded the following approaches to affirmative action, including those that: create a strategy for equitable access to education; collect data on FNIM and release findings to the public; provide funding to support various FNIM initiatives related to education; and those that include culturally appropriate curricula. Of these approaches, both Canadian and Brazilian documents had strategies to promote equitable access to education and to include culturally representative curricula.

\title{
Discussion
}

\footnotetext{
${ }^{1}$ The quotes of the Federal Law 12.711/2012 and 11.645/2008 were translated from Portuguese to English by the authors.

${ }^{2}$ It is also important to mention that in 2016, an addition to the Quotas'Law provided spots for students with disabilities.
} 
The TRC's calls to action and the Brazilian laws have approaches to affirmative action that are shared and will be explored further, however, they have clear differences which are indicative of their differing contexts. Within Brazil, currently, all the federal universities and federal institutes of education are supposed to offer $50 \%$ of all their spots to black, pardos, Indigenous, economically vulnerable students and students with disabilities. This affirmative policy has allowed the number of Brazilians who are racialized as non-white to double in post-secondary education in a decade, as evidenced by IBGE (2015). Within Canada, reserving 50\% of enrollment to marginalized students is unheard of (primarily because racialized demographics are more diverse) that said, there are institutions that reserve enrollments for members of given racialized groups (these allocations vary from one institution to the next), which suggests their efficacy.

Similarly, while the TRC has calls to action that are related to collecting data and acquiring funding, these approaches were not mentioned in the Brazilian documents analyzed. The reason for this is primarily that Brazil is already collecting extensive data through the IGBE on racialized groups and their standards of living. It is evident that Canada is lacking this information in regard to education and when reports are published they are not made annually (CBC Radio Canada 2018). Similarly, there were many calls to action in the TRC that pertained to receiving funding for various educational initiatives and the Brazilian laws had no mention of funding. Brazil has post-secondary institutions that are in the private sector (e.g catholic universities) and in the public sector, where students in the public sector can attend courses for free (no tuition fees) at universities and federal institutes of education maintained by the Brazilian government. Thus, the requirement to fund these programs and offset costs in federal institutions of education is already coming from the federal government. Since the TRC's calls to action have been posed the calls relating to funding for postsecondary education are currently in progress with the call to "develop and fund aboriginal content in education" (TRC 2015, 289) being categorized as underway (CBC Radio Canada 2018).

That being said, both countries had documents that called for introducing culturally representative curricula of racialized minority groups into mainstream education. This is not without its challenges as a superficial curriculum can be created and taught: through prejudice, preconceptual, misrepresented and stereotyped ideas about the minority groups' culture and history; a lack of didactic resources to introduce these topics in the curricula, and an inexperienced teaching force (Russo \& Paladino 2016, Sales Pereira 2011). The TRC's calls to action took a proactive stance to mitigate these issues by stating that new Aboriginal education legislation must include "full participation and informed consent of Aboriginal peoples" (TRC 2015, 197).

Culturally representative curricula have been known to combat what Codjoe (2006) refers to as the mediocre monocultural classroom experience. It is also a powerful tool to redress internalized racial oppression, which certain racialized groups experience due to a White Eurocentric curricula (Sensoy \& DiAngelo 2012). Internalized racial oppression occurs when a person of Colo[u]r, consciously and subconsciously, accepts the negative representation or invisibility of people of Colo[ $\mathrm{u}] \mathrm{r}$ in media, education, medicine, science, and all other aspects of society" (Sensoy \& DiAngelo 2012, 113). Thus, it is no surprise that the TRC and the Federal Law 11.645/2008 require curricula to be representative of racialized groups that have been traditionally marginalized. Within Brazil, there is a consensus that this approach is a breakthrough in regard to affirmative action as it promotes Human Rights to repair the damages caused over centuries. (Russo \& Paladino 2016, Sales Pereira 2011, Silva 2014, Da Silva 2010).

Although, we believe it is important to have these groups represented in curricula we also believe that it is necessary to pair this with "culturally relevant pedagogy" - a learner-centered approach that makes use of cultural competence and requires sociopolitical consciousness (LadsonBillings 2012). Geneva Gay (2010) posits that culturally responsive teaching affirms students' cultures by: teaching to and through their strengths; communicating in ways that students understand best; allowing students to communicate in ways relevant to them; changing curricular content to include critical analyses; and using pedagogical strategies that reach various learning preferences. Culturally responsive pedagogy in praxis has proven to be efficacious in aiding the 
learning of students including those who would otherwise be marginalized (e.g. those racialized as Black and having low socioeconomic status (Dei 2008; Emdin 2010; Ladson-Billings 2012).

Regarding supportive programming in post-secondary education, both Canadian and Brazilian institutions make use of students' centers. For instance, Centers of Afro-Brazilian and Indigenous Studies (Núcleos de Estudos Afro-Brasileiros e Indígenas- NEABIs) at universities and federal institutes of education were created in Brazil as a response to the documents analyzed, while some Canadian universities have had these institutions prior to the publishing of the TRC (e.g. Lakehead University). These centers connect professors, university students, and religious leaders who are representational of the racialized group as well as those who are allies; they can be linked to social movements (e.g. Idle no more); and they have access to professionals (e.g. social workers) who work at the institution. The main goals are to fight racism and to support racialized groups. To achieve these goals, some strategies from Brazil are outlined (as these centers do not have a crosscountry policy in Canada and vary depending on institution), as shown in table 3.

Table 3. Main Strategies of Centers of Afro-Brazilian and Indigenous Studies

\begin{tabular}{|l|l|}
\hline Strategies & Means to achieve \\
\hline $\begin{array}{l}\text { Professional } \\
\text { Development }\end{array}$ & $\begin{array}{l}\text { Promoting short-term courses, lectures and events in order to spread elements } \\
\text { and topics of Afro-Brazilian and Indigenous culture and history. (IFSP, 2015; } \\
\text { IFRS, 2019; UFPB, 2019; UTFPR, 2015) }\end{array}$ \\
\hline $\begin{array}{l}\text { Didactic } \\
\text { Materials }\end{array}$ & $\begin{array}{l}\text { Organize and make available didactic materials as books, articles, reports, videos } \\
\text { and music related to Afro-Brazilian and Indigenous culture and history. (IFSP, } \\
\text { 2015; IFRS, 2019; UFPB, 2019; UTFPR, 2015) }\end{array}$ \\
\hline $\begin{array}{l}\text { External } \\
\text { community } \\
\text { engagement }\end{array}$ & $\begin{array}{l}\text { Invite leaderships of Afro-Brazilian and Indigenous religions and also } \\
\text { leaderships from social movements to attend events, round-table discussions, } \\
\text { share knowledge and build reports and institutional documents. Promote free and } \\
\text { open courses to the local community in order to promote awareness regarding } \\
\text { Afro-Brazilian and Indigenous culture and history. (IFSP, 2015 \& IFRS, 2019) }\end{array}$ \\
\hline $\begin{array}{l}\text { Fighting } \\
\text { racist } \\
\text { attitudes }\end{array}$ & $\begin{array}{l}\text { Identify racism attitudes in the educational environment, answering back with } \\
\text { educational initiatives and, also to "'to establish a permanent forum for anti- } \\
\text { racist reflection to, together with public authorities, promote racial equality." } \\
\text { (IFSP, 2015, p. 4) }\end{array}$ \\
\hline $\begin{array}{l}\text { Research and } \\
\text { Studies }\end{array}$ & $\begin{array}{l}\text { Publicize research already existent related to Afro-Brazilian and Indigenous } \\
\text { culture and history. Give support to research groups committed to new studies } \\
\text { related to the topic (IFSP, 2015; UFPB, 2019; IFRS, 2019; UTFPR, 2015). }\end{array}$ \\
\hline
\end{tabular}

As a product and outcome of the changes enforced by the Federal Law 11.645/2008 and Federal Law 12.711/2012, the Centers of Afro-Brazilian and Indigenous Studies (as well as Aboriginal Student Centers) have played an important role in re-centering the histories of their respective groups. Producing didactic materials, which show achievements accomplished by non-white people in science, architecture, law, for instance, hidden and historically denied facts, enabling students and professors to develop a sense of respect and belonging with Afro-Brazilian an Indigenous cultures. Moreover, the centers are spaces that value and motivate research related to their racialized group. Aims, like getting the community together with the educational institutions to be aware of issues of racism are also important factors of support that these centers offer. 


\section{Future research}

Although, an analysis of these documents has shown some approaches to affirmative action future research is needed to determine the outcomes of these actions (particularly in Canada where these calls are yet to be taken up or where these calls are just beginning to be utilized). Though access to post-secondary education has increased for the marginalized groups the types of courses that students racialized as non-white have been accessing are of concern. Given the labor market is deeply unequal in Brazil, wherein huge difference of wages among professions are noticed, that is not a matter of individual choice, but also represents how far non-white students are having the chance to pursue social and economically valued careers. Ristoff (2014) by analyzing data from Brazilian federal universities came up with interesting findings about the profile of university students: a) although the number of students racialized as non-white in courses as Medicine, Dentistry, Law and Psychology has been increasing, the rates show a still underrepresented number of non-white students when the proportion of students is compared to the total in Brazilian society; b) on the other hand, courses which do not yield high salaries (Social Sciences, Social Work, Education, History, Geography, Letters, Mathematics, Music, Theater and Pedagogy) concentrate a higher number of non-white students. In short, in spite increasing access to post-secondary education, there are disparities among which courses they are accessing and their career outcomes, which need to be explored in further research.

\section{Conclusion}

By analyzing two very significant documents for Brazil and one monumental report for Canada (Quotas' Law - Federal Law 12.711/2012, Federal Law 11.645/2008, and the Truth and Reconciliation Final Summary Report) to identify approaches to affirmative action, we noticed that approaches took the form of: creating a strategy for equitable access to education; collecting data on racialized groups who are marginalized and releasing findings to the public; providing funding to various support initiatives for the racialized group in relation to education; and including culturally appropriate curricula/programming. The use of culturally relevant curricula/programming and the development of strategies to increase access to post-secondary education were integral to both countries. We believe that the integration of said curricular content should be coupled with culturally responsive pedagogy, however these documents did not suggest this strategy. In addition, our analysis revealed that implementation of the mentioned affirmative approaches in these countries started belatedly, after the pressure of social movements and organizations, in the first decade of the 2000s.

Nonetheless, in Brazil, the actions, programs, and policies that became federal law, enabled a meaningful social change in post-secondary education. Although students racialized as black and indigenous usually tend not to enter careers with high paying salaries (Ristoff 2014), they are now occupying Brazilian campuses more than ever before (IBGE 2015). Consequently, due to the Brazilian federal laws analyzed in this article, Afro-Brazilian and Indigenous culture and history have started to be taught in an official manner, being included in the curricula of schools and becoming a field of interest and research for post-secondary institutions teacher education programs. All these measures play a crucial role to re-signify the social and cultural representation of populations who are racialized as indigenous and black in Brazil.

Regarding Canada, the TRC's Calls to Action have inaugurated an attempt for Canadians to recognize and repair historical mistakes and damages caused to FNIM, through the residential "school" system (Moran, 2017). The calls pertaining to education make it clear that the Canadian government must provide funding in this domain. Since, the publishing of this report the calls to action that require funding have been designated as in progress, meaning that projects have been proposed or are underway. This is a step in the right direction and shows that the federal government values the use of affirmative action in education and is in favor of a move towards equity. Although, to ensure the efficacy of these measures - as well as to explore the outcomes of 
these actions in Brazil - it is necessary that further research is conducted and reports are publicly disseminated. Overall, we believe the affirmative action approaches mentioned in these documents are a necessary step, one that we hope will lead - whether directly or indirectly - to fighting systemic racism in these societies.

\section{Acknowledgements}

This paper is related to the research project named Comparative study related to the role of Canadian and Brazilian civil society organizations in developing public policies in education, developed by the researcher Michelli Aparecida Daros, who received funds from the Coordenação de Aperfeiçoamento de Pessoal de Nivel Superior (Brazil) and also from the Merit scholarship program for foreign students- Fonds de recherche, nature et technologies- Québec (Canada).

\section{References}

Brasil. 2008. "Lei $N^{o} 11.645$, de 10 de março de 2008. Altera a Lei no 9.395, de 20 de dezembro de 1996, modificada pela Lei $\mathrm{n}^{\circ} 10.639$, de 9 de janeiro de 2003, que estabelece as diretrizes e bases da educação nacional, para incluir no currículo oficial da rede de ensino a obrigatoriedade da temática "História e Cultura Afro-Brasileira e Indígena" [Law No. 11,645 from March 10, 2008. Amends Law No. 9.395 from December 20, 1996, as amended by Law No. 10.639, from January 9, 2003, which establishes the guidelines and bases of national education, to include in the official curriculum of the educational network, the obligation of the theme "AfroBrazilian and Indigenous History and Culture] Retrieved from: http://www2.camara.leg.br/legin/fed/lei/2008/lei11645-10-marco-2008-572787-publicacaooriginal-96087-pl.html.

Brasil. 2010. "Estatuto da Igualdade Racial. Lei No 12.288, de 20 de julho de 2010. Institui o Estatuto da Igualdade Racial; altera as Leis $\mathrm{n}^{\circ}$ 7.716, de 5 de janeiro de 1989, 9.029, de 13 de abril de 1995, 7.347, de 24 de julho de 1985, e 10.778, de 24 de novembro de 2003." [Statute of Racial Equality. Law No. 12.288, from July $20,2010$. Establishes the Statute of Racial Equality; amends Laws Nos. 7.716, from 5 January 1989, 9.029, from 13 April 1995, 7.347, from 24 July 1985 and 10.778 from November 24, 2003]. Retrieved from: http://www2.senado.leg.br/bdsf/bitstream/handle/id/496308/000898128.pdf.

Brasil. 2012. "Lei 12.711, de 29 de agosto de 2012. Dispõe sobre o ingresso nas universidades federais e nas instituições federais de ensino técnico de nível médio e dá outras providências" [Law 12.711, from August 29, 2012. Provides for entry into federal universities and federal institutions of technical secondary education and provides other measures]. Retrieved from http://www.planalto.gov.br/ccivil_03/_ato20112014/2012/lei/112711.htm.

Carleton, S. 2016. "Decolonizing childhood.” Canadian Dimension (50)2: 1.

CBC Radio Canada. (2018, March 9). "Beyond 94: Truth and reconciliation in Canada." Retrieved from https://newsinteractives.cbc.ca/longform-single/beyond-94.

Codjoe, H. 2006. "The role of an affirmed black cultural identity and heritage in the academic achievement of African-

Canadian students." Intercultural Education 17(1): 33-54. https://doi.org/10.1080/14675980500502271

Da Silva, M. D. P. 2010. "A temática indígena no currículo escolar à luz da lei 11.645/2008". [The indigenous theme in the school curriculum in light of the law 11.645 / 2008] Cadernos de Pesquisa[Research Notebooks], 17(2).

Dei, G. 2008. "Schooling as Community: Race, Schooling, and the Education of African Youth." Journal of Black Studies, 38(3): 346-366. https://doi.org/10.1177/0021934707306570.

Emdin, C. 2010. Urban Science Education for the Hip-Hop Generation. Rotterdam; Boston: Sense Publishers.

Gay, G. 2010. Culturally responsive teaching: theory, research, and practice (2nd ed). New York: Teachers College.

IBGE. 2015. "Síntese de Indicadores Sociais. Uma análise das condições de vida da população brasileira 2015”[ Synthesis of Social Indicators. An analysis of the living conditions of the Brazilian population 2015]. Rio de Janeiro: IBGE.

IBGE. 2017. "População chega a 205,5 milhões, com menos brancos e mais pardos e pretos" [Population reaches 205.5 million, with less whites and more pardos and blacks]. Retrieved from https://agenciadenoticias.ibge.gov.br/agencia-noticias/2012-agencia-de-noticias/noticias/18282-populacaochega-a-205-5-milhoes-com-menos-brancos-e-mais-pardos-e-pretos.

IFSP. 2015. "Núcleo de Estudos Afro-Brasileiros e Indígenas. Regulamento Interno"[ Center for Afro-Brazilian and Indigenous Studies. Internal Regulation]. Retrieved from http://prx.ifsp.edu.br/images/pdf/Neabi.pdf.

IFRS. 2019. "Núcleo de Estudos Afro-Brasileiros e Indígenas. Neabi".[Center for Afro-Brazilian and Indigenous Studies. Neabi] Retrieved from https://ifrs.edu.br/feliz/extensao/neabi/.

Kellough, J. E. 2006. "Affirmative action: The concept and the controversy." In Understanding affirmative action: Politics, discrimination, and the search for justice (pp. 3-19). Washington, DC: Georgetown University Press.

Ladson-Billings, G. 2012. "Through a glass darkly: The persistence of race in education research \& scholarship." Educational Researcher 41(4): 115-120. https://doi.org/10.3102/0013189X12440743 
Legacy of Hope Foundation 2001. Where are the children? Retrieved from: http://wherearethechildren.ca/en/stories/

Moraes Silva, G., \& de Souza Leão, L. T. 2012. "O paradoxo da mistura. Identidades, desigualdades e percepção de discriminação entre brasileiros pardos”. [The paradox of blending. Identities, inequalities and perception of discrimination among pardos Brazilians.] Revista Brasileira de Ciências Sociais [Brazilian Journal of Social Sciences] 27(80).

Moran, R. 2017. "Truth and Reconciliation Commission." Retrieved from https://www.thecanadianencyclopedia.ca/en/article/truth-and-reconciliationcommission?gclid=EAIaIQobChMIq9OXzeP14AIV1rbACh0y4AE1EAAYASAAEgLE4PD_BwE

PNAD. 2017. "Pesquisa Nacional por Amostra de Domicílios. Educação 2017. PNAD Contínua" [National Household Sample Survey. Education 2017. PNAD Continuous]. Retrieved from https://biblioteca.ibge.gov.br/visualizacao/livros/liv101576_informativo.pdf .

Ristoff, D. 2014. "The new profile of the Brazilian Campus: an analysis of the the socioeconomic profile of undergraduate students." Avaliação: Revista da Avaliação da Educação Superior [Journal of Higher Education Assessment] 19(3).

Russo, K., \& Paladino, M. 2016. "The law n. 11.645 and the teacher's vision of Rio de Janeiro on Indigenous subject at school." Revista Brasileira de Educação[Brazilian Journal of Education] 21(67): 897-921.

Sales Pereira, J. 2011. "Diálogos sobre o Exercício da Docência - recepção das leis 10.639/03 e 11.645/08”[ Dialogues on the Exercise of Teaching - reception of laws 10.639 / 03 and 11.645 / 08]. Educação \& Realidade [Education \& Reality], 36 (1): 147-172.

Sensoy, Ö., \& DiAngelo, R. J. 2012. Is everyone really equal? An introduction to key concepts in social justice education. New York: Teachers College Press.

Silva, E. 2013. "Dia do Índio: a folclorização da temática indígena na escola". [Indigenous Day: the folklore of the indigenous theme in the school ]. Construir Noticias [Building News], V. 72, p. 35-41.

Silva, E. 2015. "Ensino e sociodiversidades indígenas: possibilidades, desafios e impasses a partir da lei 11.645/2008" [Indigenous teaching and sociodiversities: possibilities, challenges and impasses from the law 11,645/2008]. Revista De Humanidades[Journal of Humanities] 15(35): 21-37. Retrieved from https://periodicos.ufrn.br/mneme/article/view/7485

Sowell, T. 2004. Affirmative action around the world: An empirical study. New Haven, UNITED STATES: Yale University Press. Retrieved from http://ebookcentral.proquest.com/lib/ottawa/detail.action?docID=3420094

Truth and Reconciliation Commission of Canada (Ed.). 2015. Final report of the Truth and Reconciliation Commission ofCanada. Toronto: James Lorimer \& Company Ltd., Publishers.

UFPB. 2019. "Núcleo de Estudos e Pesquisas Afro-Brasileiros e Indígenas". [Center for Afro-Brazilian and Indigenous Studies and Research]. Retrieved from http://www.cchla.ufpb.br/neabi/index.php/institucional.

UTFPR 2015. "Núcleo de Estudos Afro-Brasileiros e Indígenas" [Center for Afro-Brazilian and Indigenous Studies and Research]. Retrieved from https://neabiutfpr.wordpress.com/2016/05/04/vi-seminario-presenca-africana/

Valente, R. R., \& Berry, B. J. L. 2017. "Performance of Students Admitted through Affirmative Action in Brazil." Latin American Research Review 52(1): 18-34. DOI: http://doi.org/10.25222/larr.50.

Walker, J. 2009. The Indian residential schools Truth and Reconciliation Commission. Ottawa: Library of Parliament. 